\title{
Optimal levels of water and salt in the growth of giant sweet clone cactus forage
}

\author{
Níveis ótimos de água e sal no crescimento de palma forrageira clone doce gigante \\ Niveles óptimos de agua y sal en el crecimiento del forraje de cactus clon dulce gigante
}

Received: 12/03/2021 | Reviewed: 12/13/2021 | Accept: 12/14/2021| Published: 12/21/2021

\author{
Álefe Chagas de Lima Costa \\ ORCID: https://orcid.org/0000-0001-7021-4037 \\ Universidade Federal Rural de Pernambuco, Brasil \\ E-mail: alefechagas@outlook.com \\ Antonio Dennys Melo de Oliveira \\ ORCID: https://orcid.org/0000-0002-6370-8124 \\ Universidade Federal Rural de Pernambuco, Brasil \\ E-mail: dennysmelo15@gmail.com \\ João Pedro Soares Caraciolo \\ ORCID: https://orcid.org/0000-0001-9806-7681 \\ Universidade Federal Rural de Pernambuco, Brasil \\ E-mail: joaopscaraciolo@gmail.com \\ Leandro Ricardo Rodrigues de Lucena \\ ORCID: https://orcid.org/0000-0001-6985-7668 \\ Universidade Federal Rural de Pernambuco, Brasil \\ E-mail: leandroricardo_est yahoo.com.br \\ Maurício Luiz de Mello Vieira Leite \\ ORCID: https://orcid.org/0000-0003-4241-241X \\ Universidade Federal Rural de Pernambuco, Brasil \\ E-mail: nopalea21@yahoo.com.br
}

\begin{abstract}
Forage cactus is perennial growth plant, resistance to drought adaptation to hot climate regions, being considered important for the development of livestock. In this study objective was estimate the morphometrics measures of forage cactus Giant Sweet clone associate the optimal levels water and salt. Design used was completely randomized, composed of four levels of water replacement, using the crop evapotranspiration (25, 50, 75 and 100\%.Etc) and four levels of salinity $(0,2,4$ and $8 \mathrm{dS} / \mathrm{m})$, obtained through the concentrations of $(\mathrm{NaCl})$ salts corresponding to 0 , 1.16, 2.32 and $4.64 \mathrm{~g} / \mathrm{L}$, respectively. The morphometric measures of cladodes were evaluated 20 times during the experimental period. Response surface was used to estimate the optimal levels water and salt that maximizing the morphometric measures of the cladodes. Water level in range of $54 \%$ and $64 \%$, and 3.5 to $5.3 \mathrm{dS} / \mathrm{m}$ of saline level promote greater development of the Giant Sweet clone without changing the morphological characteristics of plant, generating greater phytomass yield.
\end{abstract}

Keywords: Morphometric characteristics; Nopalea cochenillifera; Response surface.

\section{Resumo}

A palma forrageira é uma planta de crescimento perene, resistente à seca e se adapta a regiões de clima quente, sendo considerada importante para o desenvolvimento da pecuária. Neste estudo objetivou-se estimar as medidas morfométricas de cactus forrageiro clone doce gigante, associadas aos níveis ótimos de água e sal. O delineamento utilizado foi inteiramente casualizado, composto por quatro níveis de reposição hídrica, utilizando a evapotranspiração da cultura $(25,50,75$ e $100 \%$.Etc) e quatro níveis de salinidade $(0,2,4$ e $8 \mathrm{dS} / \mathrm{m})$, obtidos através das concentrações de sais $(\mathrm{NaCl})$ correspondentes a $0,1,16,2,32$ e 4,64 g/L, respectivamente. As medidas morfométricas dos cladódios foram avaliadas 20 vezes durante o período experimental. A superfície de resposta foi usada para estimar os níveis ótimos de água e sal que maximizam as medidas morfométricas dos cladódios. Os níveis de água na faixa de 54\% e $64 \%$, e 3,5 a $5,3 \mathrm{dS} / \mathrm{m}$ de nível salino promovem maior desenvolvimento do clone doce gigamte sem alterar as características morfológicas da planta, gerando maior rendimento de fitomassa.

Palavras-chave: Características morfométricas; Nopalea cochenillifera; Superfície de resposta.

\section{Resumen}

El cactus forrajero es una planta perenne, resistente a la sequía y que se adapta a regiones de clima cálido, siendo considerada importante para el desarrollo de la ganadería. El objetivo de este estudio fue estimar las medidas morfométricas del clon gigante dulce de forraje de cactus, asociadas a niveles óptimos de agua y sal. El diseño utilizado fue completamente al azar, consistente en cuatro niveles de reposición de agua, utilizando la evapotranspiración del cultivo $(25,50,75$ y $100 \%$.Etc) y cuatro niveles de salinidad $(0,2,4$ y 8 dS / m), obtenidos 
mediante las concentraciones de sales $(\mathrm{NaCl})$ correspondientes a 0, 1,16, 2,32 y 4,64 g / L, respectivamente. Las medidas morfométricas de los cladodios se evaluaron 20 veces durante el período experimental. La superficie de respuesta se utilizó para estimar los niveles óptimos de agua y sal que maximizan las medidas morfométricas de los cladodios. Niveles de agua en el rango de 54\% y 64\%, y 3,5 a 5,3 dS / m de nivel salino promueven un mayor desarrollo del clon dulce gigamte sin alterar las características morfológicas de la planta, generando mayor rendimiento de fitomasa.

Palabras clave: Características morfométricas; Nopalea cochenillifera; Superficie de respuesta.

\section{Introduction}

Use Forage cactus is commonly grown in semiarid areas because it shows great water-use efficiency due to its CAM metabolism, is an important animal-feed alternative, they present perennial growth, resistance to drought and low tolerance to salt stress (Pereira et al., 2018; Freire et al., 2018, Diniz et al., 2017). Water deficit cause changes in the anatomy, physiology and biochemistry of plants, which can affect all stages of development, up to growth and productivity (Scalon et al., 2011; Yahmed et al., 2016; El-Mageed et al., 2018).

Forage plants with the influence of water stress suffer with salt stress, since the waters of the semiarid regions have high concentrations of salts (Silva et al., 2018). Accumulation of salts in the soil promotes an unfavourable environment for plant development, because it negatively alters crop growth reducing the productivity of forage plants in agricultural areas (Munns \& Tester, 2008). Saline stress induces a reduction in $\mathrm{CO}_{2}$ assimilation and consequently less plant growth and less dry matter production (Silva et al., 2018).

Under these conditions make it necessary to study the growth of forage cactus. Adjustment of growth curves is an important tool to gain knowledge of the plant's growth and its phenological stages (Lucena et al., 2018; Moura et al., 2020). Response surface methodology (RSM) stands out in the adjustment of growth curves, because that is useful when response of interest is influenced by two explanatory variables, and objectived optimize the response as a function of the combined effects of these variables (Lucena et al., 2019a and 2019b).

Studies reporting the association between water and saline stress in forage cactus at other stages of development were not found. Soon the objective of this study was estimate the morphometric meansure of N. cochenillifera Giant Sweet clone associating water and salt stresses using response surface.

\section{Methodology}

Research was carried in Federal Rural University of Pernambuco, Brazil (elevation: 429 m, latitude: $7^{\circ} 56^{\prime} 15^{\prime \prime} \mathrm{S}$ and longitude: $38^{\circ} 18^{\prime} 45^{\prime}$ E). According to Koppen, the climate condition is BSwh' (Leite et al., 2019). The soil used in the experiment (Typical Haplic Cambisol Ta Eutrophic), was collected from the 0-20 cm layer. After analysis was characterized by the following chemical attributes: $\mathrm{pH}($ water $)=7.20 ; \mathrm{P}($ extractor Mehlich $\mathrm{I})=40 \mathrm{mg} \mathrm{dm}^{-3} ; \mathrm{K}^{+}=0.45 ; \mathrm{Ca}^{2+}=5.3 ; \mathrm{Mg}^{2+}=$ $1.10 ; \mathrm{Al}^{3+}=0,0 \mathrm{cmolc} \mathrm{dm}^{-3}$ (Lucena et al., 2020).

Experimental design used was completely randomized, consisting of four levels of water based on crop evapotranspiration $(25,50,75$ and $100 \%$.ETc), and four levels saline, with four repetitions. For the saline deficit, were used the resulting from different electrical conductivities $(0,2,4$ and $8 \mathrm{dS} / \mathrm{m})$, obtained through the concentrations of $(\mathrm{NaCl})$ salts corresponding to $0,1.16,2.32$ and $4.64 \mathrm{~g} / \mathrm{L}$, respectively. Forage cacti were planted in pots with a capacity of $14.41 \mathrm{dm}^{3}$. Pots were arranged at a spacing of $0.3 \times 0.3 \mathrm{~m}$ and placed on brick blocks to avoid direct contact with soil.

The plant height, length, width, thickness, and number of cladodes and cladode area were evaluated. Cladode area was estimated by the product of the length by the width of the cladodes according to the methodology of Lucena et al. (2019c) and Leite et al. (2020). The evaluations were carried out every 15 days, totalling 20 evaluations in period. The values of the studies 
variables were recorded in Excel spreadsheets and analyses carried out using the R-project software, version 2.13.1 for Windows.

Plant height $(\mathrm{PH})$, cladode length $(\mathrm{L})$, cladode width $(\mathrm{W})$, cladode thickness $(\mathrm{T})$ and cladode area $(\mathrm{A})$ were evaluated using the response surface methodology. Response surface was defined as the geometric representation obtained from the response as a function of two quantitative factors (water and salt levels). Response surface defined in the present study is described by:

$$
\mathrm{Y}=\mathrm{f}\left(\mathrm{X}_{1}, \mathrm{X}_{2}\right)+\varepsilon=\beta_{0}+\beta_{1} \mathrm{X}_{1}+\beta_{2} \mathrm{X}_{2}+\beta_{\mathrm{a}} \mathrm{X}_{1} \mathrm{X}_{2}+\beta_{4} \mathrm{X}_{1}^{2}+\beta_{5} \mathrm{X}_{2}^{2}+\varepsilon
$$

where, $Y$ is the response of morphometric variable; $X_{1}$ and $X_{2}$ are the factors (water and salinity level), $\beta_{0}, \beta_{1}, \beta_{2}, \beta_{3}, \beta_{4}$ and $\beta_{5}$ are the unknown parameters and $\varepsilon$ random error follows normal distribution of mean 0 and constant variance $\sigma^{2}$.

In order to find the optimal levels of water $(\mathrm{H})$ and salinity $(\mathrm{S})$ that maximize the studies variables of $N$. cochenillifera Giant Sweet clone we use the stationary point. This point is calculated solve the following equation system defined below:

$\frac{\partial \widehat{\mathrm{Y}}}{\partial \mathrm{X}_{1}}=\widehat{\beta}_{1}+2 \widehat{\beta}_{2} \mathrm{X}_{1}+\widehat{\beta}_{5} \mathrm{X}_{2}=0$

and

$\frac{\partial \widehat{\mathrm{Y}}}{\partial \mathrm{X}_{2}}=\widehat{\beta}_{2}+2 \widehat{\beta}_{4} \mathrm{X}_{2}+\widehat{\beta}_{5} \mathrm{X}_{1}=0$

where, $\mathrm{Y}^{v}=\left[\mathrm{Y}_{1}, \mathrm{Y}_{2}, \ldots, \mathrm{Y}_{\mathrm{N}}\right], \mathrm{X}$ is the matrix $\mathrm{N}$ x p; $\mathrm{p}=6 ; \beta$ is a vector $\mathrm{p} \times 1$ of unknown parameters and $\varepsilon^{v}=\left[\varepsilon_{1}, \varepsilon_{2}, \ldots, \varepsilon_{\mathbb{N}}\right]$.

To evaluate the adequacy of the model, was used the determination coefficient of the adjusted model $R_{a j \mathrm{~L}}^{2}$.

\section{Results and Discussion}

Table 1 shows results for the height plant, length, width, thickness and cladode area of Giant Sweet clone at 330 days after planting. 
Table 1. Average and standard deviation of the Giant Sweet clone morphometric measures as a function of crop evapotranspiration (ETc) and salt stress at 330 days after planting.

\begin{tabular}{|c|c|c|c|c|}
\hline \multirow{2}{*}{$\begin{array}{l}\text { Water level } \\
\text { (\% ETc) }\end{array}$} & \multicolumn{4}{|c|}{ Water salinity level (dS/m) } \\
\hline & 0 & 2 & 4 & 8 \\
\hline & \multicolumn{4}{|c|}{ Plant height $(\mathrm{cm})$} \\
\hline $25 \%$ & $45.3 \pm 5.5$ & $38.9 \pm 7.1$ & $47.2 \pm 2.2$ & $40.8 \pm 3.2$ \\
\hline $50 \%$ & $44.3 \pm 7.3$ & $44.4 \pm 8.4$ & $46.2 \pm 5.1$ & $41.8 \pm 3.3$ \\
\hline $75 \%$ & $37.9 \pm 6.2$ & $40.5 \pm 6.2$ & $40.5 \pm 4.5$ & $40.8 \pm 8.2$ \\
\hline \multirow[t]{2}{*}{$100 \%$} & $46.3 \pm 6.1$ & $44.3 \pm 5.3$ & $39.9 \pm 3.3$ & $36.6 \pm 5.1$ \\
\hline & \multicolumn{4}{|c|}{ Cladode length $(\mathrm{cm})$} \\
\hline $25 \%$ & $27.0 \pm 4.3$ & $24.3 \pm 5.3$ & $28.0 \pm 3.1$ & $26.5 \pm 2.8$ \\
\hline $50 \%$ & $26.3 \pm 3.7$ & $27.9 \pm 3.3$ & $26.7 \pm 5.2$ & $23.0 \pm 2.8$ \\
\hline $75 \%$ & $24.0 \pm 2.3$ & $24.4 \pm 5.2$ & $23.9 \pm 5.1$ & $26.8 \pm 3.2$ \\
\hline \multirow[t]{2}{*}{$100 \%$} & $28.0 \pm 4.6$ & $25.4 \pm 3.1$ & $22.9 \pm 3.3$ & $22.7 \pm 4.5$ \\
\hline & \multicolumn{4}{|c|}{ Cladode width (cm) } \\
\hline $25 \%$ & $12.3 \pm 1.1$ & $11.2 \pm 0.5$ & $12.4 \pm 1.3$ & $12.4 \pm 2.3$ \\
\hline $50 \%$ & $12.8 \pm 1.5$ & $11.7 \pm 1.9$ & $12.4 \pm 2.2$ & $9.9 \pm 2.0$ \\
\hline $75 \%$ & $10.6 \pm 0.3$ & $10.8 \pm 2.1$ & $10.5 \pm 2.1$ & $12.4 \pm 1.1$ \\
\hline \multirow[t]{2}{*}{$100 \%$} & $12.8 \pm 2.7$ & $12.2 \pm 0.7$ & $10.6 \pm 0.6$ & $9.5 \pm 0.5$ \\
\hline & \multicolumn{4}{|c|}{ Cladode thickness (mm) } \\
\hline $25 \%$ & $19.6 \pm 1.1$ & $16.2 \pm 1.5$ & $18.5 \pm 1.3$ & $18.1 \pm 0.6$ \\
\hline $50 \%$ & $18.1 \pm 1.3$ & $18.8 \pm 1.3$ & $16.6 \pm 2.1$ & $16.5 \pm 1.1$ \\
\hline $75 \%$ & $18.3 \pm 0.7$ & $17.6 \pm 1.1$ & $17.3 \pm 1.8$ & $15.7 \pm 1.7$ \\
\hline \multirow[t]{2}{*}{$100 \%$} & $19.1 \pm 1.3$ & $15.8 \pm 0.5$ & $16.1 \pm 1.4$ & $16.9 \pm 1.8$ \\
\hline & \multicolumn{4}{|c|}{ Cladode area $\left(\mathrm{cm}^{2}\right)$} \\
\hline $25 \%$ & $333.1 \pm 81.3$ & $271.8 \pm 53.1$ & $346.5 \pm 66.3$ & $329.1 \pm 89.2$ \\
\hline $50 \%$ & $337.3 \pm 75.9$ & $325.4 \pm 62.7$ & $329.1 \pm 89.7$ & $227.7 \pm 33.7$ \\
\hline $75 \%$ & $254.7 \pm 29.3$ & $261.8 \pm 89.5$ & $243.2 \pm 91.3$ & $332.3 \pm 71.2$ \\
\hline $100 \%$ & $358.8 \pm 95.7$ & $308.0 \pm 51.2$ & $242.2 \pm 47.8$ & $209.0 \pm 39.3$ \\
\hline
\end{tabular}

Source: Authors.

In O. ficus-indica the morphometric measures of cladodes suffer negatively influence with the increase in the level of salinide applied in the irrigation water, thus reducing their values (Amador et al., 2001; Salazar \& Véliz, 2007; Gajender et al., 2014).

Queiroz et al. (2015) verified in $O$. stricta that the morphometric measures and number of cladodes are affected with the increase of reference evapotranspiration, while Freire et al. (2018) verified reduce in the growth of cladodes of $N$. cochenillifera Little Sweet clone using different saline levels and irrigation water. Situation found in the present study, which compromised the vegetative development in the plant.

Cladode area, plant height, cladode length and width showed quadratic behavior as a function of water and saline level as well as interaction between stresses, Table 2 and Figures 1 to 4, respectively

Table 2. Response surface of the area, height, length, width and thickness of Giant Sweet clone, adequacy criteria $\left(\mathrm{R}^{2}\right)$ and optimal levels of \%ETc and water salinity.

\begin{tabular}{llllll}
\hline Morphometric characteristics & \multicolumn{1}{c}{ Response surface } & $\mathrm{R}^{2}$ & $\mathrm{H}_{0}$ & $\mathrm{~S}_{0}$ & $\mathrm{Y}_{0}$ \\
\hline Cladode area & $7.41 \mathrm{H}+29.79 \mathrm{~S}-0.049 \mathrm{H}^{2}-1.11 \mathrm{~S}^{2}-0.348 \mathrm{HS}$ & 0.924 & 63.1 & 3.53 & 286.28 \\
Plant height & $1.19 \mathrm{H}+4.51 \mathrm{~S}-0.008 \mathrm{H}^{2}-0.219 \mathrm{~S}^{2}-0.041 \mathrm{HS}$ & 0.968 & 62.8 & 4.42 & 47.45 \\
Cladode length & $0.71 \mathrm{H}+2.5 \mathrm{~S}-0.0048 \mathrm{H}^{2}-0.11 \mathrm{~S}^{2}-0.024 \mathrm{HS}$ & 0.964 & 62.6 & 4.53 & 27.90 \\
Cladode width & $0.30 \mathrm{H}+1.11 \mathrm{~S}-0.002 \mathrm{H}^{2}-0.043 \mathrm{~S}^{2}-0.012 \mathrm{HS}$ & 0.951 & 54.7 & 5.29 & 10.53 \\
Cladode thickness & $0.4 \mathrm{H}+0.75 \mathrm{~S}-0.002 \mathrm{H}^{2}-0.0126 \mathrm{HS}$ & 0.913 & 59.3 & 12.9 & 16.7 \\
\hline
\end{tabular}

$\mathrm{H}_{0}$ : optimal level of\% Etc; $\mathrm{S}_{0}$ : optimal level of salinity; $\mathrm{Y}_{0}$ : maximum point. ETc -crop evapotranspiration. Source: The authors. 
Freire et al. (2018) verified quadratic behavior for the Little Sweet clone cladode width, maximizing their width (5.37 $\mathrm{cm}$ ) with an optimum salinity level of $2.57 \mathrm{dS} / \mathrm{m}$ with an accuracy of $54.05 \%$ In the present study, the cladode width maximized by $10.53 \mathrm{~cm}$ when used $5.29 \mathrm{dS} / \mathrm{m}$ and with accuracy of $95.1 \%$.

Through of the response surface of cladode area verified that using the water level of $63.1 \% . E T c$ and $3.53 \mathrm{dS} / \mathrm{m}$ of salinity, maximized the cladode area of the $N$. cochenillifera in $286.28 \mathrm{~cm}^{2}$ at 330 days after planting, Figure 1.

Figure 1. Response surface of the cladode area of $N$. cochenillifera.

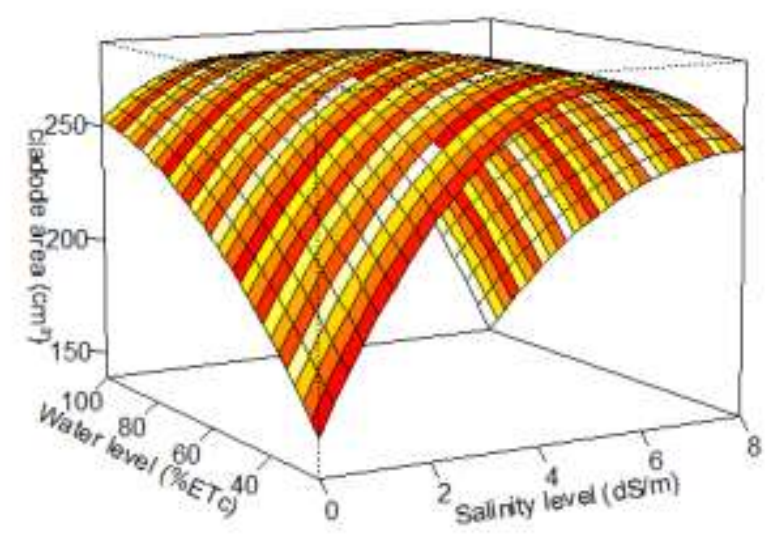

Source: Authors.

Plant height of $N$. cochenillifera had its maximum at $47.45 \mathrm{~cm}$ at 330 days after planting when water level of 62.8\%.ETc and $4.42 \mathrm{dS} / \mathrm{m}$ of salinity was used, Figure 2. Similar results were reported by Gajender et al. (2014) in O. ficusindica. 
Figure 2. Response surface of the plant height of $N$. cochenillifera.

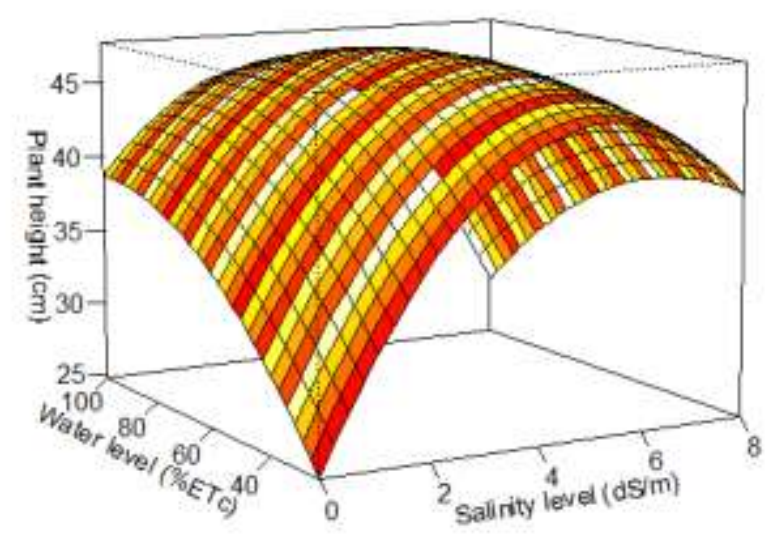

Source: Authors.

Response surface of the length of the cladodes maximized its length by $27.9 \mathrm{~cm}$ when $62.6 \%$. ETc and $4.53 \mathrm{dS} / \mathrm{m}$ were used at 330 days after planting, Figure 3.

Figure 3. Response surface of the cladode length of $N$. cochenillifera.

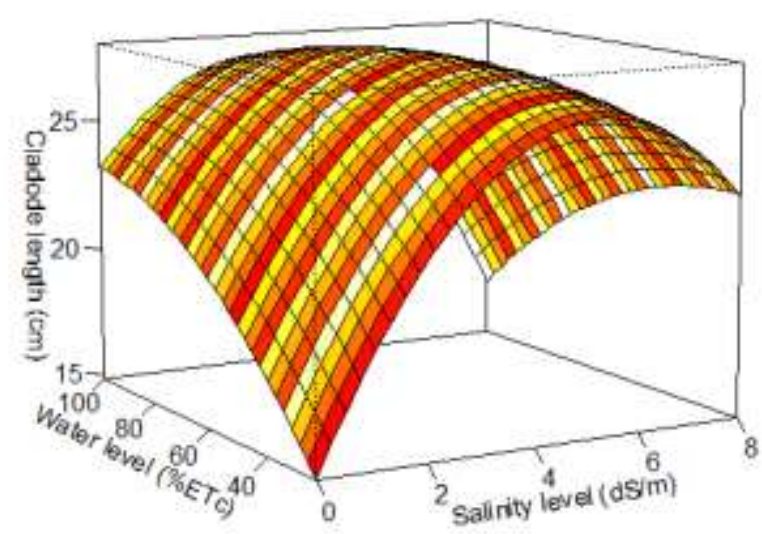

Source: Authors.

Cladode length of the $O$. ficus-indica is affected when salinity levels above $3 \mathrm{dS} / \mathrm{m}$ (Amador et al., 2001). Queiroz et al. (2015) verified that cladode length of $O$. stricta is maximized in $2.78 \mathrm{~cm}$, when $0 \%$ ETc used. Through the response surface 
generated for the cladode width, when $54.7 \%$.ETc and $5.29 \mathrm{dS} / \mathrm{m}$ are used, maximize in $10.53 \mathrm{~cm}$ at 330 days after planting, Figure 4.

Figure 4. Response surface of the cladode width of $N$. cochenillifera.

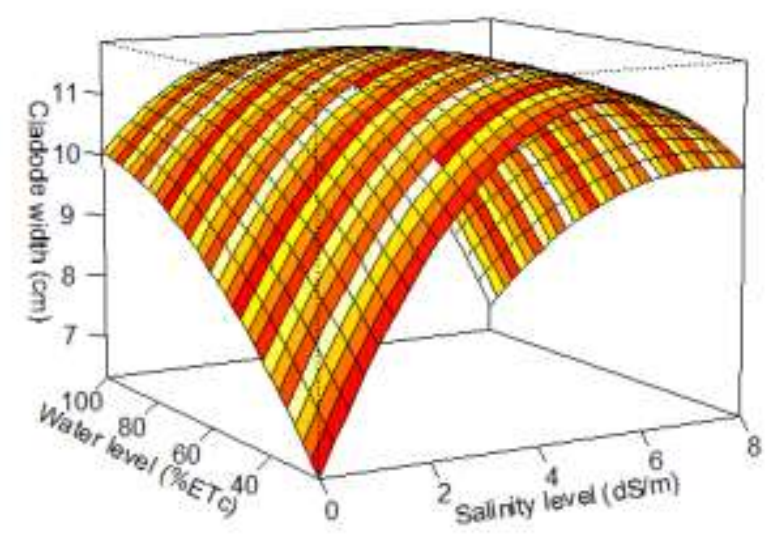

Source: Authors.

The cladode width of $O$. ficus-indica is affected when salinity levels above $3 \mathrm{dS} / \mathrm{m}$ used (Amador et al., 2001). To maximize the cladode width of Little Sweet clone in $5.37 \mathrm{~cm}$, Freire et al. (2018) used optimum level of $2.57 \mathrm{dS} / \mathrm{m}$ of salinity. Queiroz et al. (2015) verified that when $0.0 \%$.ETc was used, maximized the cladode width of $O$. stricta in $2.46 \mathrm{~cm}$.

Cladode thickness showed quadratic behavior as a function of water stress and linear in relation to the salinity level, as well as interaction between the two stresses, Table 2 and Figure 5. 
Figure 5. Response surface of the cladode thickness of $N$. cochenillifera.

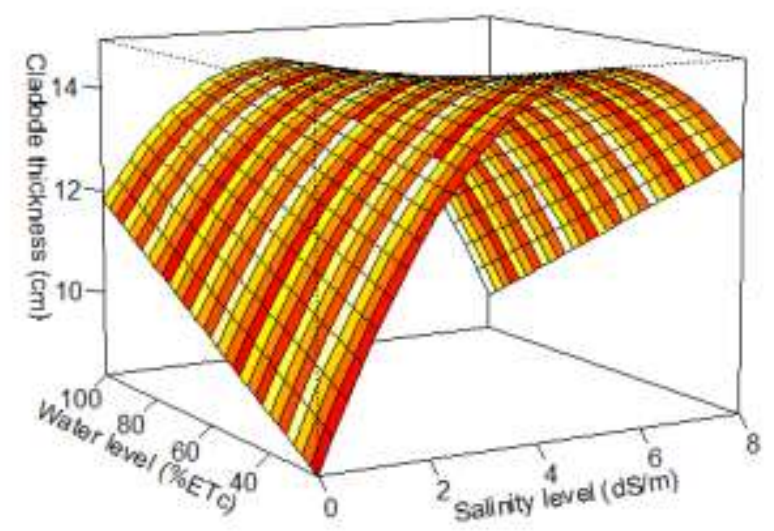

Source: Authors.

Freire et al. (2018) observed that the cladode thickness of little sweet clone present linear behavior to different salinity level with $30.21 \%$ precision of explain. Observed that the response surface for cladode thickness showed an optimal level of 59.3\%.ETc and $12.9 \mathrm{dS} / \mathrm{m}$ maximizing the thickness in $16.7 \mathrm{~mm}$ at 330 days after planting, Figure 5. Freire et al. (2018) maximized the thickness of Little Sweet clone in $0.28 \mathrm{~cm}$ using a level of $3 \mathrm{dS} / \mathrm{m}$ of salinity. Queiroz et al. (2015) verified that when $0 \%$.ETc was used, maximized the cladode thickness of Opuntia stricta in $0.2 \mathrm{~cm}$.

\section{Conclusion}

Water and salt stresses modifies the morphometric measures of Nopalea cochenillifera Giant Sweet clone, compromising the vegetative growth of the plant. The crop evapotranspiration in range $54 \%$ and $64 \%$, and 3.5 to $5.3 \mathrm{dS} / \mathrm{m}$ of saline level promote greater growth of the Giant Sweet clone without changing the morphological characteristics, implies in greater phytomass yield. Future work should be carried out evaluating the optimal levels of salt and shading to verify better yield of forage cactus.

\section{References}

Amador, B. M., Avila, A. C., Diéguez, E. T., Garibay, A. N. \& Jones, H. G. (2001). Effects of $\mathrm{NaCl}$ salinity on growth and production of young cladodes of Opuntia ficus-indica. Journal Agronomy \& Crop Science, 187(4), 269-279. https://doi.org/10.1046/j.1439-037X.2001.00529.x

Diniz, W. J. S., Silva, T. G. F., Ferreira, J. M. S., Santos, D. C., Moura, M. S. B., Araújo, G. G. L. \& Zolnier, S. (2017). Forage cactus-sorghum intercropping at different irrigation water depths in the Brazilian Semiarid Region. Pesquisa Agropecuária Brasileira, 52(9), 724-733. https://doi.org/10.1590/S0100204X2017000900004

El-Mageed, T. A. A., El-Samnoudi, I. M., Ibrahim, A. E. M. \& Tawwab, A. R. A. (2018). Compost and mulching modulates morphological, physiological responses and water use efficiency in sorghum (bicolor L. Moench) under low moisture regime. Agricultural Water Management, 208, 431-439. https://doi.org/10.1016/j.agwat.2018.06.042.

Freire, J. L., Santos, M. V. F., Dubeux Jr, J. C. B., Neto, E. B., Lira, M. A., Cunha, M. V., Santos, D. C., Amorim, S. O. \& Mello, A. C. L. (2018). Growth of cactus pear cv. Miúda under different salinity levels and irrigation frequencies. Anais da Academia Brasileira de Ciências, 90(4), 3893-3900. https://doi.org/10.1590/0001-3765201820171033 
Gajender, G., Singh, G., Dagar, J. C., Lal, K. \& Yadav, R. K. (2014). Performance of edible cactus (Opuntia ficus-indica) in saline environments. Indian Journal of Agricultural Sciences, 84(4), 509-519.

Leite, M. L. M. V., Lucena, L. R. R., Cruz, M. G., Sá Jr, E. H. \& Simões, V. J. L. P. (2019). Leaf area estimate of Pennisetum glaucum by linear dimensions. Acta Scientiarum Animal Science, 41, e42808. https://doi.org/10.4025/actascianimsci.v41i1.42808

Leite, M. L. M. V., Lucena, L. R. R., Oliveira, A. D. M., Costa, A. C. L., Anjos, F. L. Q., Farias, I. M., Simões, V. J. L. P. \& Almeida, M. C. R. (2020). Cladode area and weight of Nopalea cochenillifera clones as a function of morphometric characteristics. Journal of the Professional Association for Cactus Development, 22, 8-28.

Lucena, L. R. R., Pereira, J. S. \& Leite, M. L. M. V. (2018). Avaliação do modelo de regressão potência no crescimento de Nopalea cochenillifera em função do fracionamento do cladódio. Revista Brasileira de Biometria, 36(3), 578-587. https://doi.org/10.28951/rbb.v36i3.238

Lucena, L. R. R., Simões, V. J. L. P. \& Leite, M. L. M. V. (2019a). Superfície de resposta de medidas morfométricas de Pennisetum glaucum submetidos ao estresse salino. Archivos de Zootecnia, 68(264), 540-545. https://doi.org/10.21071/az.v68i264.4993.

Lucena, L. R. R., Leite, M. L. M. V., Borja, C. R. S. \& Costa, A. C. L. (2019b). Superfície de resposta no desenvolvimento do capim Pangolão submetidos a déficit hídrico e aplicação de bioestimulante. Biomatemática, 29(1), 17-34.

Lucena, L. R. R., Leite, M. L. M. V., Cruz Jr, C. B., Carvalho, J. D., Santos, E. R. \& Oliveira, A. D. M. (2019c). Estimation of cladode area of Nopalea cochenillifera using digital images. Journal of the Professional Association for Cactus Development, 21, 32-42.

Lucena, L. R. R., Leite, M. L. M. V., Almeida, M. C. R., Simões, V. J. L. P., Costa, A. C. L., Oliveira, A. D. M. Caraciolo, J. P. S. (2020). Millet survival submitted to associated stress using generalized gamma and Burr XII distribution. Research, Society and Development, 9(9), e895998308. http://dx.doi.org/10.33448/rsd-v9i9.8308

Moura, E. A., Lucena, L. R. R., Leite, M. L. M. V., Moura, G. A., Simões, V. J. L. P. \& Simplicio, J. B. (2020). Relation of plant height and cladode number of cactus little sweet clone consorted with pornunça. Cuban Journal of Agricultura Science, 54(2), 279-288.

Munns, R. \& Tester, M. (2008). Mechanisms of Salinity Tolerance. Annual Review of Plant Biology, 59(1), 651-681. https://doi.org/10.1146/annurev.arplant.59.032607.092911

Pereira, J. S., Leite, M. L. M. V., Cavalcante, A. B. \& Lucena, L. R. R. (2018). Crescimento inicial de Nopalea cochenillifera em função do fracionamento do cladódio. Revista Agropecuária Técnica, 39(2), 120-128. https://doi.org/10.25066/agrotec.v39i2.37995

Queiroz, M. G., Silva, T. G. F., Zolnier, S., Silva, S. M. S., Lima, L. R. \& Alves, J. O. (2015). Características morfofisiológicas e produtividade da palma forrageira em diferentes lâminas de irrigação. Revista Brasileira de Engenharia Agrícola e Ambiental, 9(10), 931-938. https://doi.org/10.1590/18071929/agriambi.v19n10p931-938

Salazar, V. A. F. \& Vélez, J. A. (2007). Respuestas de la tuna [Opuntia ficus-indica (L.) Mill.] al NaCl. Interciencia, 32(2), 125-130.

Scalon, S. P. Q., Mussury, R. M., Euzébio, V. L. M., Kodama, F. M. \& Kissmann, C. (2011). Estresse hídrico no metabolismo e crescimento inicial de mudas de mutambo (Guazuma ulmifolia Lam.). Ciência Florestal, 21(4), 655-662. https://doi.org/10.5902/198050984510.

Silva, J. R. I., Jardim, A. M. R. F., Neto, J. B., Leite, M. L. M. V. \& Teixeira, V. I. (2018). Estresse salino como desafio para produção de plantas forrageiras. Pesquisa Aplicada \& Agrotecnologia, 11(3), 127-139. https://doi.org/10.5935/PAeT.V11.N3.13

Yahmed, J. B., Oliveira, T. M., Novillo, P., Quinones, A., Forner, M. A., Salvador, A., Froelicher, Y., Mimoun, M. B., Talon, M., Ollitrault, P. \& Morillon, R. (2016). A simple, fast and inexpensive method to assess salt stress tolerance of aerial plant part: Investigations in the mandarin group. Journal of Plant Physiology, 190, 36-43. https://doi.org/10.1016/j.jplph.2015.10.008. 